\title{
Effect of structural properties of carbon-based fuels on efficiency of direct carbon fuel cells
}

\author{
Magdalena Dudek • Maciej Sitarz • Piotr Tomczyk
}

Received: 5 January 2014 /Revised: 23 February 2014 / Accepted: 25 February 2014 / Published online: 15 March 2014

(C) The Author(s) 2014. This article is published with open access at Springerlink.com

\begin{abstract}
This research is focused on the effect of supplying solid oxide fuel cells with different graphite and carbon black powders on the cells' efficiency. Before being tested in the fuel cell, the structures of carbon-based fuels were characterized by X-ray diffraction analysis, Raman spectroscopy, scanning electron microscopy, and thermal analysis method (DTA/TG). Total electrical conductivity measurements were also carried out for carbon samples. The relation between the structure and morphology of solid particles and their performance in direct carbon solid oxide fuel cells (DC-SOFC) was presented and discussed. It was found that structurally disordered carbon-based materials are the most promising fuels for oxidation in DC-SOFCs.
\end{abstract}

Keywords Direct carbon fuel cell · Solid oxide electrolytes · Graphite $\cdot$ Carbon blacks

\section{Introduction}

Combustion of carbonaceous fuels has accompanied human civilization from the very beginning. First, wood was used to produce heat and energy, then fossil coal; now, the most important role is played by natural gas and mineral oil. Unfortunately, the oxidation of carbon is inextricably linked to the formation of $\mathrm{CO}_{2}$, which is believed to affect the Earth's climate through the destructive rise of global temperatures. Because the abrupt elimination of coal from use in the power

M. Dudek $(\bowtie) \cdot$ P. Tomczyk

Faculty of Energy and Fuels, AGH-University of Science and

Technology, Al. Mickiewicza 30, 30-059 Cracow, Poland

e-mail: potoczek@agh.edu.pl

M. Sitarz

Faculty of Materials Science and Ceramics,

AGH-University of Science and Technology, Al. Mickiewicza 30,

30-059 Cracow, Poland industry is impossible, efforts are concentrated now at increasing the efficiency of power generation, including cogeneration in distributed systems, the wider use of biomass, and improvements in $\mathrm{CO}_{2}$ capture and storage (CCS) technologies [1, 2].

All these challenges can be met by the application of direct carbon fuel cells (DCFCs), which therefore has attracted growing interest over the past decade. The DCFC offers significant advantages over traditional carbon conversion technologies. It converts the chemical energy of carbon solid fuel directly into electricity without a reforming process, operates with high efficiency, and is available in small domestic units which produce electricity and heat in cogeneration [3, 4]. The flue gases emitted from a DCFC consist mostly of concentrated $\mathrm{CO}_{2}$, which can be stored in geological formations without very expensive separation. Finally, a wide variety of carbonaceous fuels can be used to feed DCFCs, including fossil coal, plastic waste, biomass, and many others [5,6]. Various types of DCFCs have been investigated recently. One of the most common classifications involves the kind of electrolyte used in the cell. Carbon fuel can be electro-oxidized with the use of alkaline, molten carbonate, and solid oxide electrolytes [7, 8].

The latter system, the direct carbon fuel cell with a solid oxide electrolyte (DC-SOFC), is believed to be the most advantageous due to its uncomplicated construction and maintenance. On the other hand, it suffers from low power density, which must be increased to make it commercially viable. In a DC-SOFC $[9,10]$, carbon can be electrochemically oxidized directly to $\mathrm{CO}_{2}$ according to Eq. 1:

$\mathrm{C}+2 \mathrm{O}^{2-} \rightarrow \mathrm{CO}_{2}+4 \mathrm{e}^{-}$

as well as in a sequence of reactions (2) and (3):

$\mathrm{C}+\mathrm{CO}_{2} \rightarrow 2 \mathrm{CO}$

$\mathrm{CO}+\mathrm{O}^{2-} \rightarrow \mathrm{CO}_{2}+2 \mathrm{e}^{-}$ 
The Boudouard reaction (2), involving $\mathrm{CO}_{2}$ and $\mathrm{C}$ as reactants, is an additional source of the $\mathrm{CO}$ consumed in reaction (3).

A DC-SOFC usually operates at temperatures between 700 and $900{ }^{\circ} \mathrm{C}$. The power density obtained from the DC-SOFC, which increases along with an increase in temperature, usually does not exceed 120 $180 \mathrm{~mW} / \mathrm{cm}^{2}$ at $850{ }^{\circ} \mathrm{C}[11,12]$. The physicochemical properties of the applied solid fuel, the construction of the cell, the compositions of electrode and electrolyte materials, the catalysts applied, and the participation of CO produced by the Boudouard reaction (2) in the overall electro-oxidation process occurring in the cell all affect the current and power densities acquired from the DC-SOFC $[13,14]$.

Although the physicochemical properties of the solid carbon fuel strongly influence the performance of a DCFC, no systematic studies have been performed concerning this issue. In this work, we investigate the effects of supplying a DC-SOFC with various carbonaceous fuels of different properties such as degree of disorder at the molecular level, morphology, and particle sizes. Special emphasis was placed on the investigations of graphite and carbon black, which are the main components of popular carbonaceous fuels.

\section{Experimental}

\section{Materials}

To produce a reliable comparative analysis, a series of experiments were done under the same experimental conditions and with identical cells; however, the cells were fed with two different types of carbonaceous fuel, namely, graphites and carbon blacks. The properties of these fuels, determined prior to oxidation in the DC-SOFC, are listed in Table 1.
Methods of carbon fuel characterization

The phase composition of all the carbon-based powder samples, both prior and subsequent to the electrochemical investigations, was evaluated by X-ray diffraction analysis (XRD) with reference to the ICDD database. The XRD measurements were carried out using a PANalytical X'Pert Pro system with monochromatic $\mathrm{CuK}_{\alpha}$ radiation. Raman studies were carried out using a Horiba Yvon Jobin LabRAM HR micro-Raman spectrometer equipped with a CCD detector. An excitation wavelength of $532 \mathrm{~nm}$ was used, with a beam intensity about $10 \mathrm{~mW}$. Acquisition time was set to $30 \mathrm{~s}$.

The thermal effects occurring during the heating of the solid carbon fuel within a temperature range of $25-1,000{ }^{\circ} \mathrm{C}$ under a helium or argon gas flow were measured by DTA and TG methods (SDT 2960, TA Instruments). The samples (ca. $50 \mathrm{mg}$ ) were ramped up at a rate of $10 \mathrm{~K} \cdot \mathrm{min}^{-1}$ in an alumina crucible. The specific surface area of carbon-based powders was determined by multipoint nitrogen adsorption at $-196^{\circ} \mathrm{C}$ (Quantachrome PoreMaster). A scanning electron microscope (Nova NanoLab SEM 1221), coupled with an EDS system, was used to characterize the morphology and chemical composition of the carbon particles. This method was also applied to examine a cross-section of a single SOFC cell prior to and subsequent to the electrochemical investigations.

In order to determine the effect of the physicochemical properties of carbon fuels on the kinetics of the Boudouard reaction (2), the powdered samples were heated in a quartz reactor at $900{ }^{\circ} \mathrm{C}$ for $120 \mathrm{~h}$ under either an $\mathrm{Ar}$ or a $\mathrm{CO}_{2}$ gas flow. Then the samples were cooled, withdrawn from the reactor, and analyzed again. The data obtained for the samples prior to and subsequent to heating were compared to determine the carbon losses which occurred during the Boudouard reaction. The electrical resistivity of the carbon pellets made of the investigated carbon fuels was measured by the fourprobe $\mathrm{AC}$ method within temperature ranges of -100 to $100{ }^{\circ} \mathrm{C}$ and 100 to $800{ }^{\circ} \mathrm{C}$ in an argon flow. The pellets were

Table 1 Characteristics of carbon fuels tested in the DC-SOFC

\begin{tabular}{|c|c|c|c|c|c|}
\hline $\begin{array}{l}\text { Designated in } \\
\text { this work as }\end{array}$ & Type of carbon fuel & Producer & $\begin{array}{l}\text { Surface } \\
\text { area }\left(\mathrm{m}^{2} / \mathrm{g}\right)\end{array}$ & $\begin{array}{l}\text { Crystalline } \\
\text { size } d_{(002)}(\mathrm{nm})\end{array}$ & $\begin{array}{l}\text { Carbon } \\
\text { content (\%wt) }\end{array}$ \\
\hline A & Graphite & USA Graphite & 12.5 & $\sim 24.6$ & 98.5 \\
\hline B & Graphite & Olmec Advanced Materials Ltd, United Kingdom & $<0.5$ & $\sim 46.3$ & 98.3 \\
\hline $\mathrm{C}$ & Pyrolytic graphite & Merck, Germany & 25.6 & $\sim 16.8$ & 97.6 \\
\hline $\mathrm{D}$ & Natural graphite & Degussa, Germany & 33.6 & $\sim 21.3$ & 96.5 \\
\hline $\mathrm{E}$ & Carbon black Vulcan XC-72 & Cabot, USA & 196.4 & $\sim 2.3$ & 99.2 \\
\hline $\mathrm{F}$ & Carbon black N220 & Konimex, Poland & 62.5 & $\sim 3.6$ & 98.3 \\
\hline
\end{tabular}


formed under isotactic pressure of $250 \mathrm{MPa}$ and then sintered at $1,000{ }^{\circ} \mathrm{C}$ for $12 \mathrm{~h}$ under an $\mathrm{Ar}$ flow.

Electrochemical investigations of DC-SOFC performance

The direct electrochemical oxidation of carbon was studied using two types of electrochemical cells (DC-SOFC), varying only in the anodic half-cell:

C $\mid 8$ YSZ $\mid$ LSM-GDC $|\mathrm{LSM}| \mathrm{O}_{2}$

$$
\mathrm{C} \mid \mathrm{Ni}-\text { YSZ }|8 \mathrm{YSZ}| \mathrm{LSM}-\mathrm{GDC}|\mathrm{LSM}| \mathrm{O}_{2}
$$

where $8 \mathrm{YSZ}$ was an electrolyte $150-\mu \mathrm{m}$ thick, consisting of $8 \mathrm{~mol} \% \mathrm{Y}_{2} \mathrm{O}_{3}$ in $\mathrm{ZrO}_{2}$; LSM was a $\mathrm{La}_{0.8} \mathrm{Sr}_{0.2} \mathrm{MnO}_{3}$ cathode material; LSM-GDC was a composite cathode material made of $\mathrm{LSM}+10 \mathrm{~mol} \% \mathrm{Gd}_{2} \mathrm{O}_{3}$ in $\mathrm{CeO}_{2}(\mathrm{GDC})$; and $\mathrm{Ni}-\mathrm{YSZ}$ was a cermetallic anode material consisting of $50 \mathrm{vol} \% 8 \mathrm{YSZ}$ and 50 vol $\%$ NiO.

Electrochemical measurements were performed within a temperature range of $500-850{ }^{\circ} \mathrm{C}$ using a PGSTAT $300 \mathrm{~N}$ potentiostat equipped with GPES (CV) and FRA (EIS) modules. The impedance spectroscopy measurements were performed within a frequency range from 0.001 to $1 \mathrm{MHz}$; the cell was polarized with $10 \mathrm{mV}$ sinusoidal voltage amplitudes.

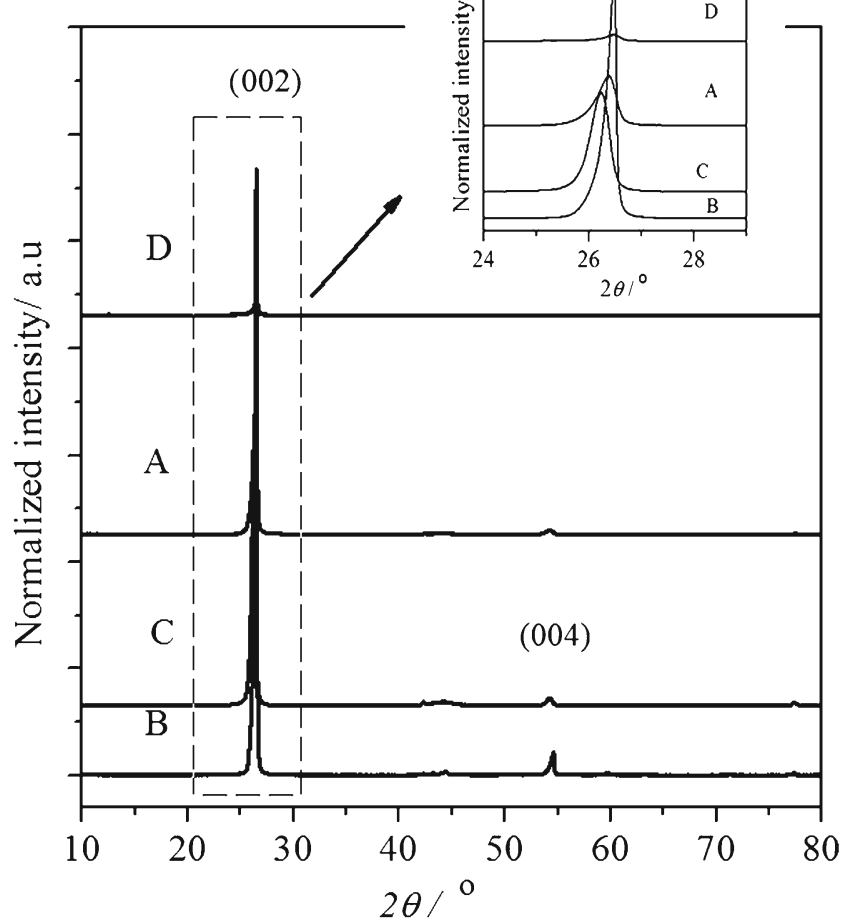

Fig. 1 The X-ray diffraction pattern recorded for graphite powders

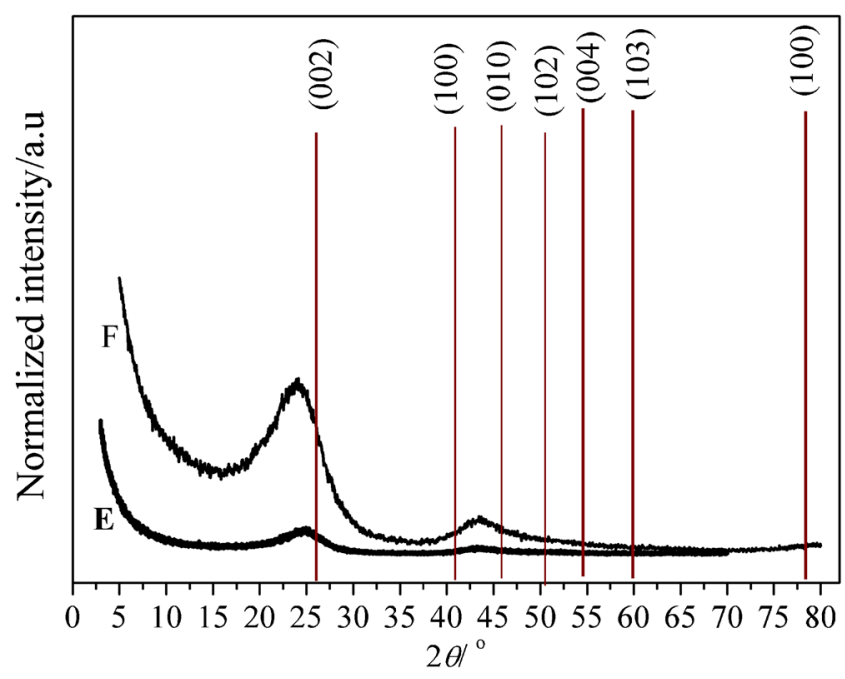

Fig. 2 The X-ray diffraction pattern recorded for carbon black powders

To analyze the impedance data, a program provided by the vendor (Metrohm, Autolab B.V.), based on a complex nonlinear regression least squares (CNRLS) fit, was used. Impedance measurements with a symmetrical cell were also carried out in order to characterize cathode performance. Symmetrical cells were fabricated by applying the same

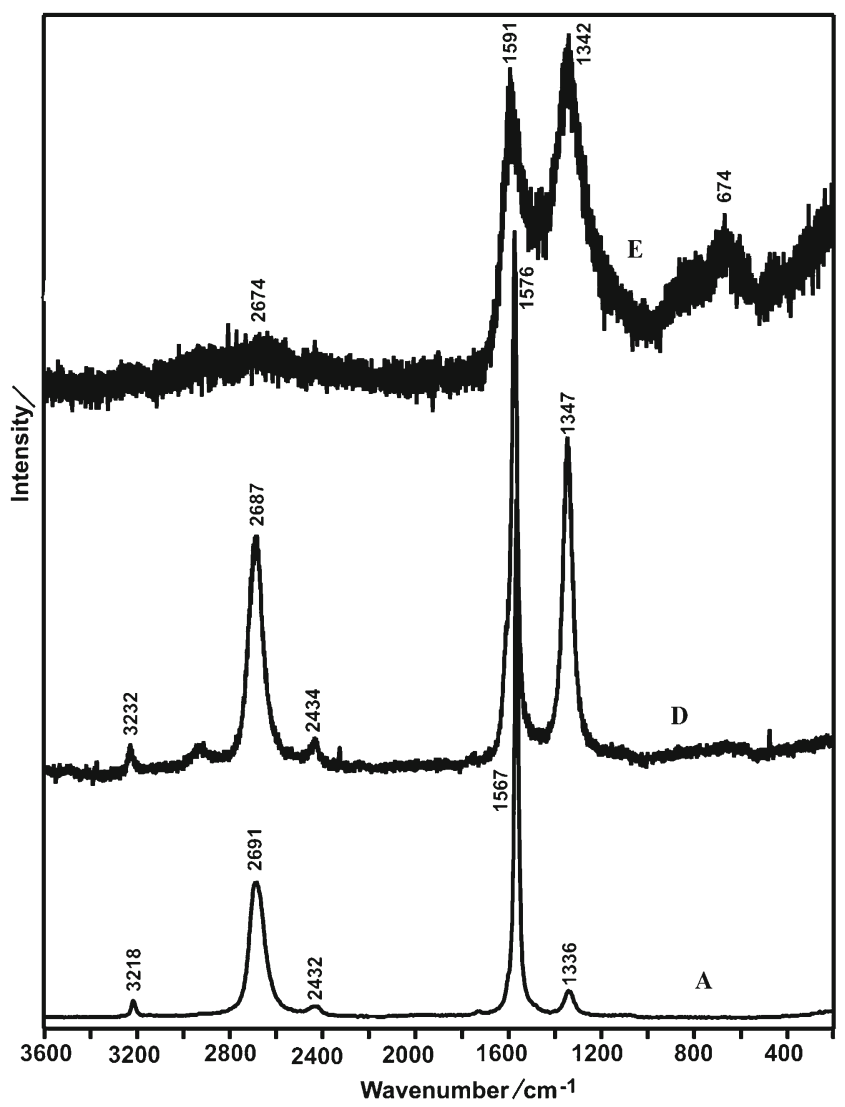

Fig. 3 The Raman spectra recorded for graphite A and D and carbon black E powders 
cathode materials and current collectors in the DC-SOFC on both sides of the $8 \mathrm{YSZ}$ electrolyte $(150-\mu \mathrm{m}$ thick, $20 \mathrm{~mm}$ in diameter). The description of the electrochemical setup of a button solid oxide fuel cell fueled by solid carbon, as well as the measurement procedure, was described in our previous papers $[15,16]$.

\section{Results}

Structural investigations of graphite and carbon black fuels

X-ray diffraction analysis revealed that investigated graphite samples A, B, C, and D consisted exclusively of a pure-phase carbon. No crystalline reflection, which is characteristic for inorganic phases and usually attributed to ashes (mineral residues), was observed for these fuels. Direct comparison of the XRD patterns (Fig. 1) recorded for the graphite powders showed noticeable differences in intensity, width, and position of peak (002). The highest and sharpest profile of (002) peak was noted for sample B. Lower and broader (002) peaks were observed for samples A and C. The (002) peak of the lowest intensity located at the highest background noise, especially at low angles, was recorded for the natural graphite (sample D).
These results can be attributed to the structural particularities of the investigated graphite fuels: a higher content of disordered graphite-type structures and the presence of structural defects are reflected in a lower and broader profile of $(002)$ peak.

As can be seen in Fig. 2, the X-ray diffraction patterns recorded for Vulcan XC-72 carbon black (sample E) and carbon black N220 (sample F) showed much lower and broader (002) peaks than graphite samples (Fig. 1). The background level of these patterns was also much higher, which is typical for disordered carbon phase. The XRD diffraction patterns presented in Fig. 2 are normalized toward the peak observed at $2 \theta=20-26^{\circ}$; the vertical lines mark the position of the tabulated graphite peaks. The patterns of similar characteristics are rather typical for a disordered carbon phase [17], including the so-called short-range graphite or turbostratic structure of the sample $[18,19]$.

The Raman spectra recorded for graphite samples A and D are presented in Fig. 3. Three well-defined bands, D, G, and $2 \mathrm{D}$, can be identified in the spectrum of graphite $\mathrm{A}$ at the approximate positions of $1,347,2,432$, and $2,688 \mathrm{~cm}^{-1}$, respectively. The strong $G$ band originates from the $E_{2 g}$ vibration mode and represents the relative motion between two $\mathrm{sp}^{2}$ carbon atoms. The $\mathrm{D}$ band comes from the $\mathrm{A}_{1 \mathrm{~g}}$ ring breathing
Fig. 4 The SEM image recorded for a graphite powder A, b graphite powder $\mathrm{D}$, and $\mathbf{c}$ carbon black E
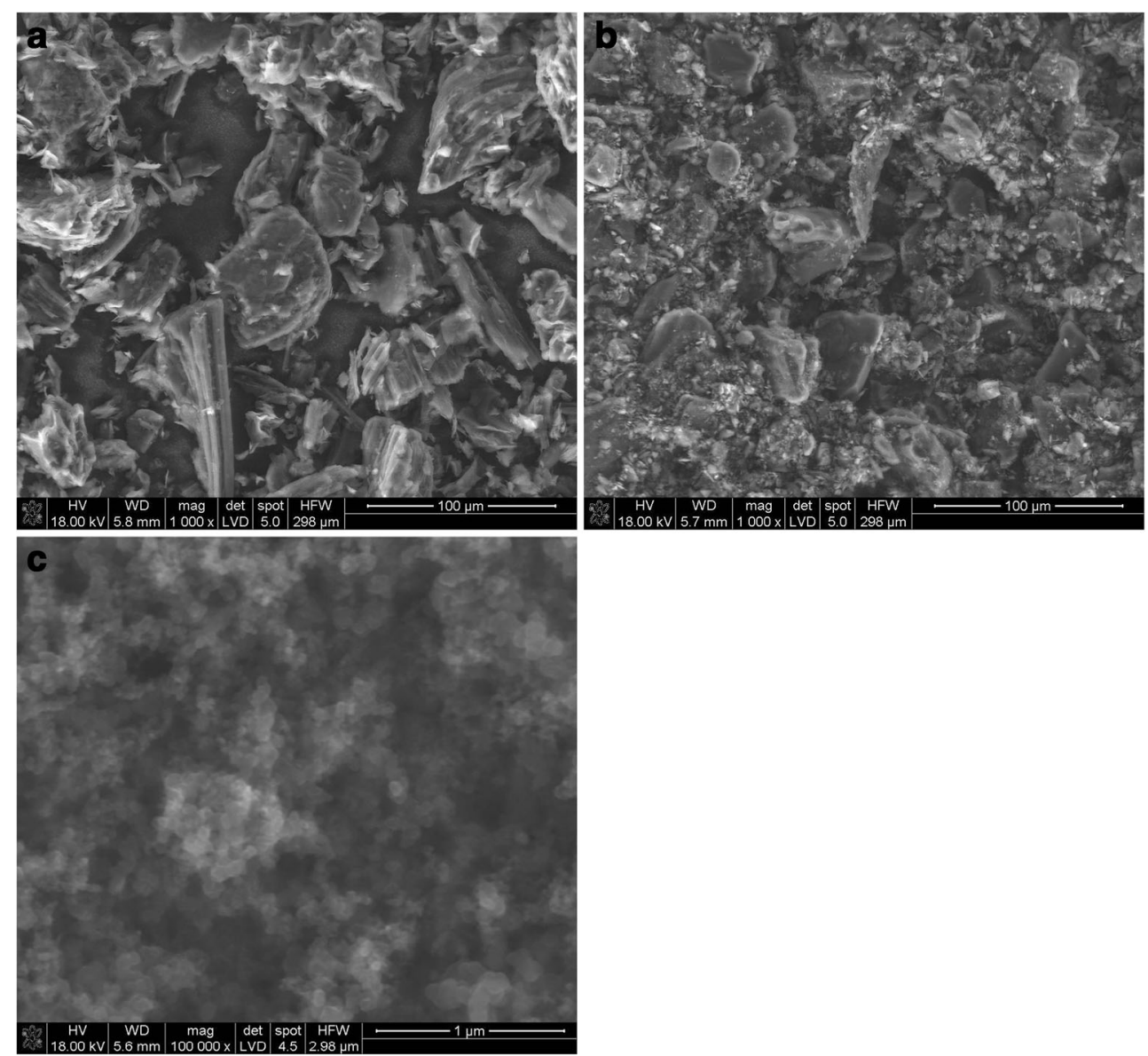
mode. It is worth emphasizing that this mode is symmetrically impossible in a perfect graphite. The very low-intensity D band indicates that the sample has a relatively non-defective graphite structure. In the case of sample D, the intensity of the $\mathrm{D}$ band is considerably higher relative to that recorded for graphite sample A. A direct comparison between the intensity ratios of the $\mathrm{D}$ to $\mathrm{G}$ band $\left(\mathrm{I}_{\mathrm{D}} / \mathrm{I}_{\mathrm{G}}\right)$ for graphites $\mathrm{A}$ and $\mathrm{D}$ indicated that a large amount of amorphic phase or defect clusters with different dimensions was present in the natural graphite (sample D). These results confirm the conclusions drawn on the basis of X-ray investigations.

The Raman spectra recorded for the Vulcan XC-72 carbon black (sample E) is also presented in Fig. 3. The first-order spectrum of carbon black (soot) generally exhibited two broad and strongly overlapping peaks with maxima at $\sim 1,347$ and $\sim 1,576 \mathrm{~cm}^{-1}$. Sadezky et al. [20] have suggested that this kind of Raman spectra of soot can be interpreted in terms of a highly disordered graphite structure. The additional peaks at $\sim 672 \mathrm{~cm}^{-1}$ correspond to the amorphic carbon phase, at $2,674 \mathrm{~cm}^{-1}$ to the $2 \mathrm{D}$ band.

Physicochemical and thermal properties of graphite and carbon black fuels

All the samples of carbon fuels investigated were ground in a planetary mill, producing smaller carbon particles and

a
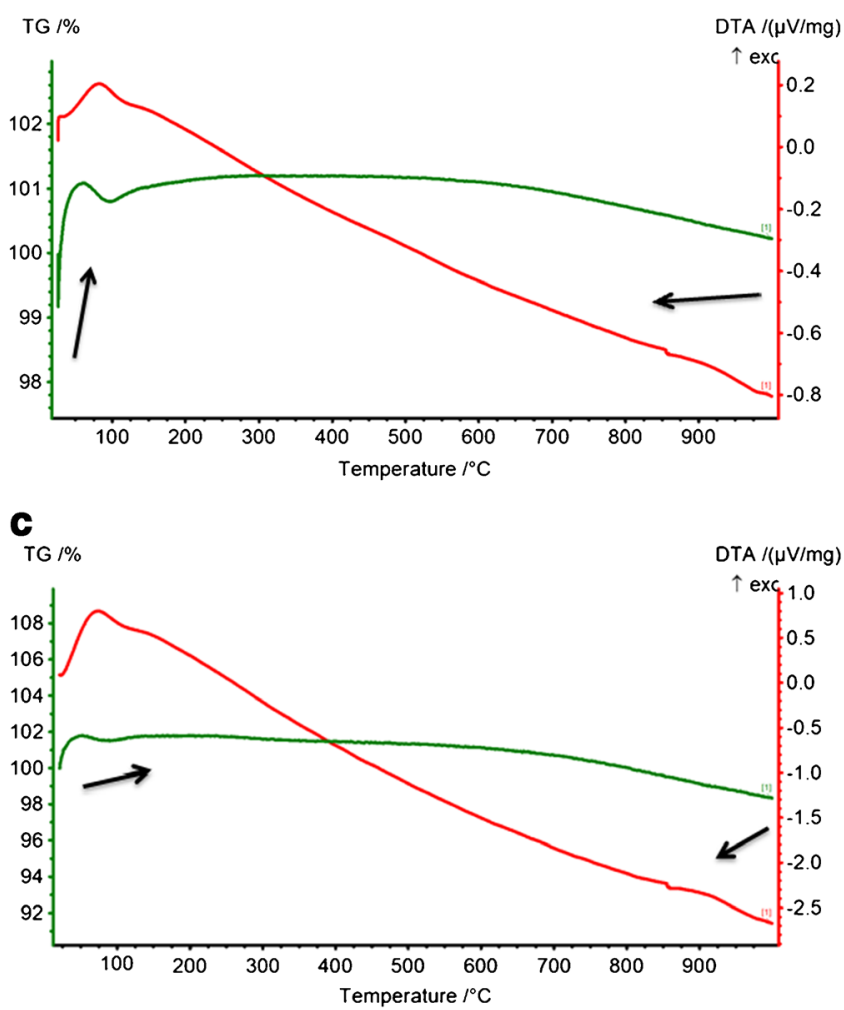

increasing their surface area. Typical SEM microphotographs of graphite and powder black powders are presented in Fig. 4a-c. Graphite sample A consisted mainly of isometric particles with dimensions ranging from $\sim 6$ to $\sim 80 \mu \mathrm{m}$, whereas the dimensions of isometric particles of natural graphite (sample D) ranged from $\sim 1$ to $\sim 40 \mu \mathrm{m}$. As observed, carbon black E (Fig. 4c) consists mainly of isometric particles with dimensions ranging from 0.2 to $0.6 \mu \mathrm{m}$.

Thermal analysis was applied to determine the losses of mass (TG) in parallel to the thermal effect (DTA) which occurred during start-up and operation of the DCSOFC fed with graphite and carbon black fuels. This analysis was performed within a temperature range of $25-1,000{ }^{\circ} \mathrm{C}$. The typical DTA/TG curves recorded for graphites $\mathrm{A}$ and $\mathrm{D}$ and carbon black $\mathrm{E}$ are presented in Fig. $5 \mathrm{a}-\mathrm{c}$.

No considerable endothermic or exothermic peaks or other thermal effects were observed above $150^{\circ} \mathrm{C}$ in the DTA curve for any of the investigated samples. The lowest mass losses $(\sim 2-3 \mathrm{wt} \%)$ were found for graphite A and Vulcan carbon black (E), the highest for natural graphite D ( $\sim 6 \% \mathrm{wt})$.

The mass losses of solid fuel in a fixed carbon bed were also determined after heating the graphite and carbon black samples at $900{ }^{\circ} \mathrm{C}$ for $120 \mathrm{~h}$. Under these conditions, the Boudouard reaction is thermodynamically favorable. After completion of the experiment, the reactor was cooled down,

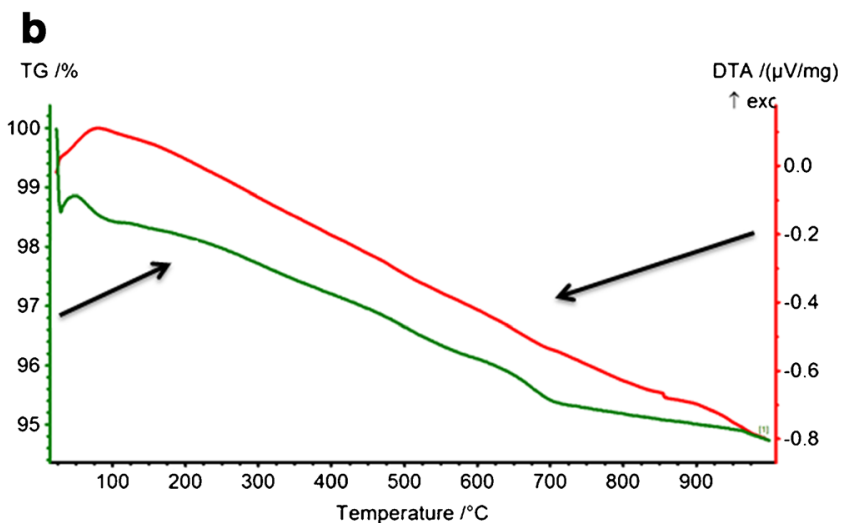

Fig. 5 The DTA, TG curves recorded for a graphite A, b graphite D, and $\mathbf{c}$ carbon black E. Argon was used as a shielding gas 
and the weight of the remaining graphite or carbon black was determined. Different consumptions of carbon were observed for the graphite and carbon black powders. High ( 41 wt\%) losses were observed for the Vulcan XC-72 (sample E, surface area $191 \mathrm{~m}^{2} / \mathrm{g}$ ) compared to low $(\sim 6 \mathrm{wt} \%)$ for graphite A (surface area $12.6 \mathrm{~m}^{2} / \mathrm{g}$ ). These losses correlate not only with the ratio of the ordering structure of carbon of the particular samples but also with the surface area of the investigated solid powders.

The impact of the transport properties of carbon-based fuels on the performance of DC-SOFCs has not been studied as of yet. Nevertheless, it is known at least that the specific electrical resistance of the carbon materials affects the ohmic polarization of the cell under loading. The dependences on temperature of the total electrical conductivity of the investigated fuels are presented in Fig. 6. A very small increase in total electrical conductivity with temperature was observed for graphite-based samples at a low temperature range. The highest electrical conductivity was found for carbon black (samples E and F), the lowest for graphite $\mathrm{A}$. The values of energy activation $\left(E_{a}\right)$ varied from 0.02 to $0.12 \mathrm{eV}$ at low temperature ranges $\left(-100\right.$ to $\left.100{ }^{\circ} \mathrm{C}\right)$. Low positive values of thermoelectric measurements were found within the analogous temperature range. All of the investigated carbon samples exhibited electrical conductivity, which is practically independent of temperature in the range $200-700{ }^{\circ} \mathrm{C}$. The values of total electrical conductivity $\sigma$ at $700{ }^{\circ} \mathrm{C}$ for graphites A-D were $0.18,0.28,0.43$, and $0.50 \mathrm{~S} / \mathrm{cm}$, respectively. In the case of the carbon black samples $\mathrm{E}$ and $\mathrm{F}$, total electrical conductivity $\sigma$ values at the same temperature were 0.75 and $0.64(\mathrm{~S} / \mathrm{cm})$, respectively.

The data available in the literature clearly indicate that the minimal initiation temperature of carbon oxidation depends on various aspects of crystallographic disorder and the characteristic scale of microcrystallinity. Weaver et al. [21] were

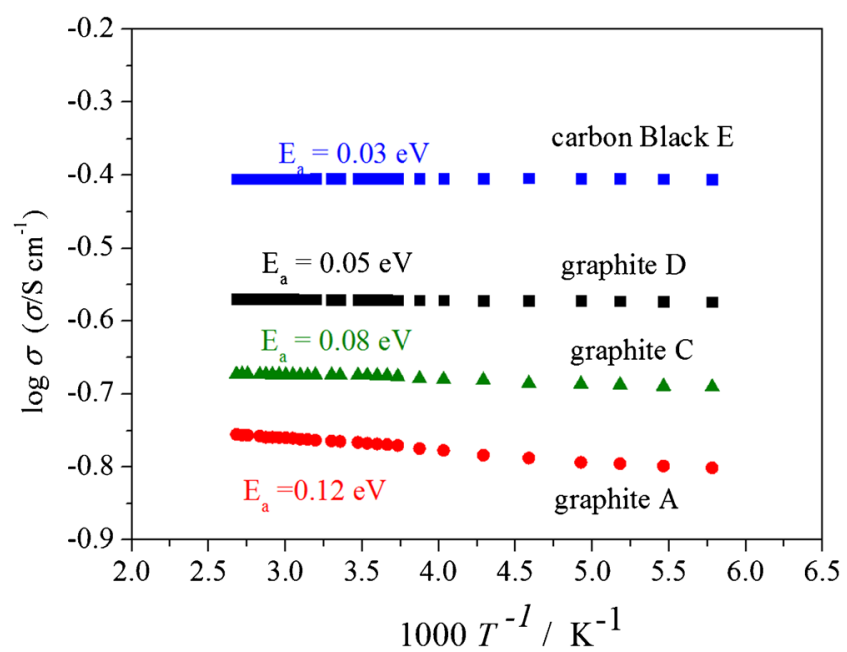

Fig. 6 The dependence of electrical conductivity $(\sigma)$ of carbon-based materials on temperature perhaps the first to recognize that the polarization of the carbon anode in the carbonate melt depended not on the specific surface area but rather on the degree of disorder. Cherepy et al. [22] conducted a more thorough examination of the dependence of the anode oxidation rate on the fixed polarization. In their work, the structure of carbon materials was characterized with the use of a crystallinity index. The current achieved at fixed polarizations $(0.2$ or $0.8 \mathrm{~V}$ below the standard cell voltage) was found to correlate with this index.

Electrochemical investigations of a DC-SOFC supplied with carbon fuel of different structural properties

In a DC-SOFC of type (4) supplied with carbon fuel, the electrochemical oxidation of carbon occurs within a limited reaction zone (Fig. 7) restricted to points of direct contact between the carbon fuel and the solid oxide electrolyte. Therefore, the morphology (isometric, irregular, needle, or laminar shapes) and dimensions of particles affect the current and power densities acquired from the cell. Typical voltage vs. current density $(U-I)$ and power density vs. current density $(P$ I) dependences determined for a DC-SOFC supplied with graphite powders are presented in Fig. 8a-b. As can be seen, the current density and power density acquired from cell (4) fueled with any type of graphite fuel are low; specifically, they do not exceed $8 \mathrm{~mW} \mathrm{~cm}^{-2}$. On the basis of the data presented in Fig. 8a-b and Table 2, it can be concluded that the

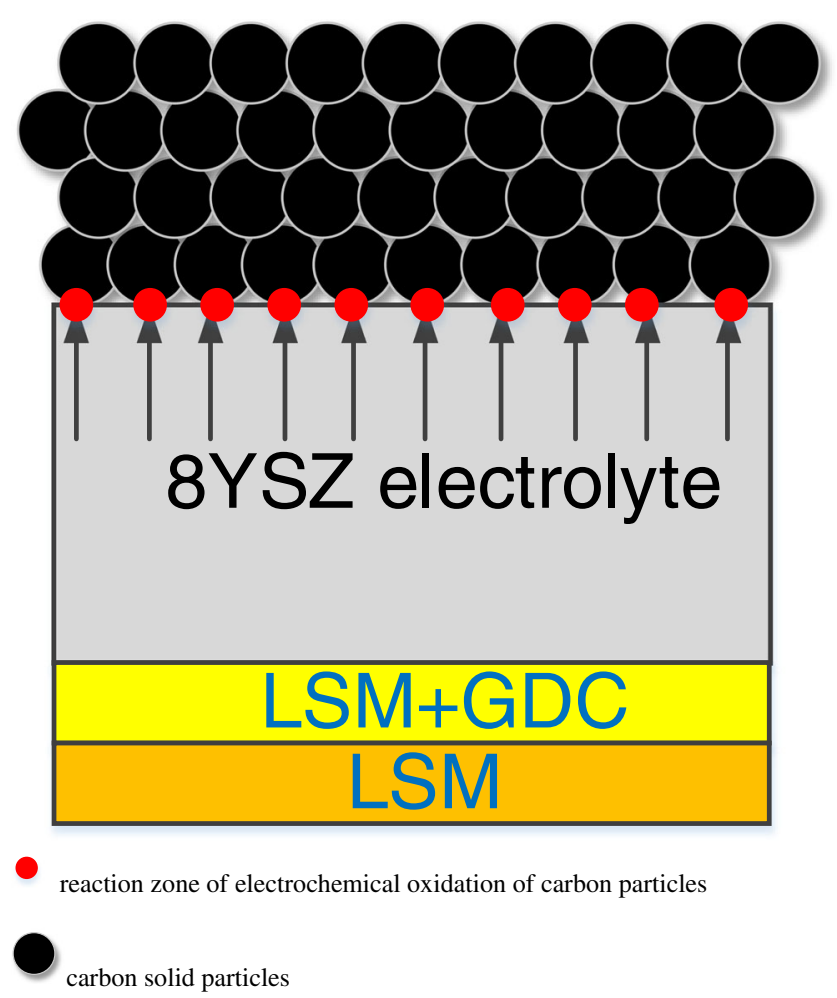

Fig. 7 The electrochemical oxidation of carbon particles on the surface of an 8YSZ oxide electrolyte 

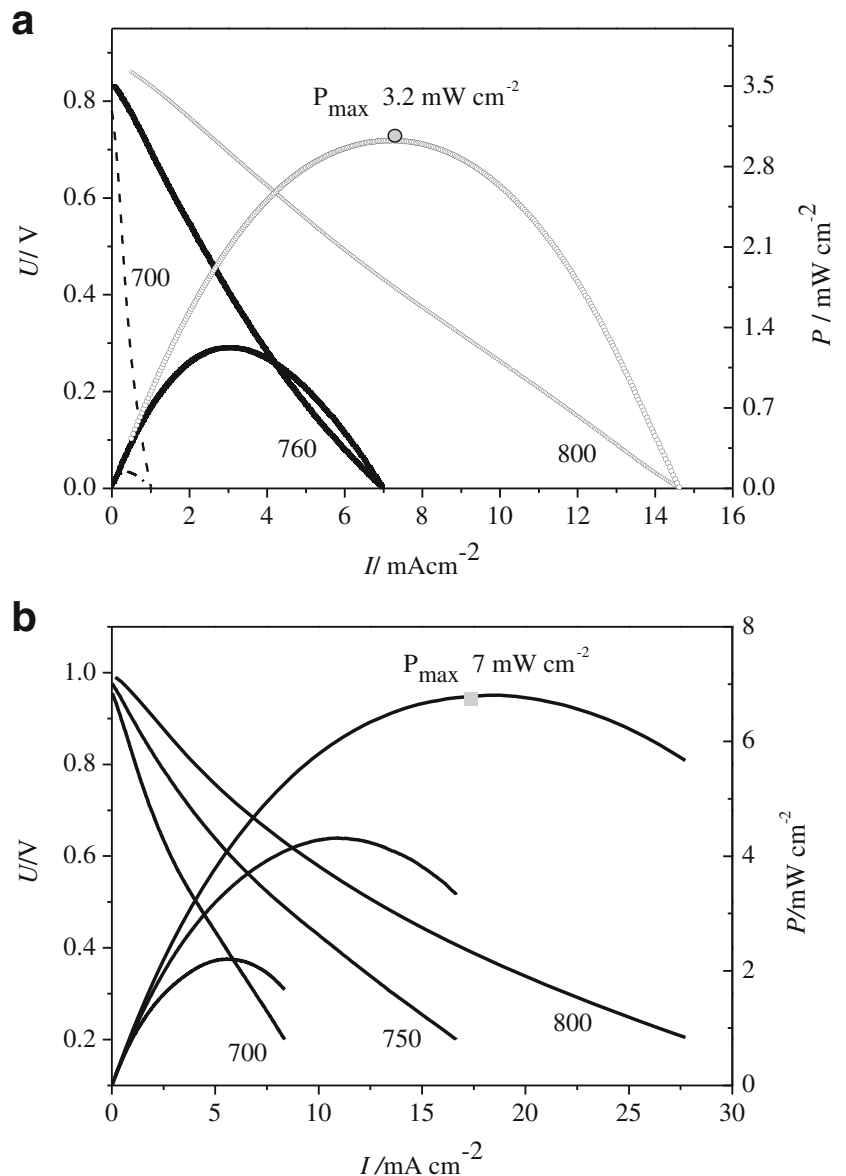

Fig. 8 The family of $U-I$ and $P-I$ curves recorded for a DC-SOFC (4) supplied with graphite A (a) or graphite D (b). Ar atmosphere over fuel. The numbers at curves denote the temperature

performance of DC-SOFC (4) improves with an increasing degree of disorder in the applied graphite powders. As can be seen, the highest values of the current density and power density were obtained from the DC-SOFC fueled with natural graphite (sample D), which is characterized by the lowest intensity of the (002) peak at the XRD pattern (Fig. 1) and the highest intensity of peak D at the Raman spectra (Fig. 3) among all types of graphite investigated. This observation justifies the correlation postulated above between the degree of crystallographic disorder and rate of electrochemical oxidation of carbon particles in the DC-SOFC.

Table 2 Maximum power of DC-SOFC type (4) supplied with a graphite powder fuel

\begin{tabular}{lll}
\hline Type of solid fuel & \multicolumn{2}{c}{$P_{\max }\left(\mathrm{mW} \mathrm{cm}{ }^{-2}\right)$} \\
\cline { 2 - 3 } & $T=700{ }^{\circ} \mathrm{C}$ & $T=800{ }^{\circ} \mathrm{C}$ \\
\hline A & 0.5 & 3.0 \\
B & 0.75 & 4.1 \\
C & 1.3 & 5.7 \\
D & 2.1 & 7.0 \\
\hline
\end{tabular}

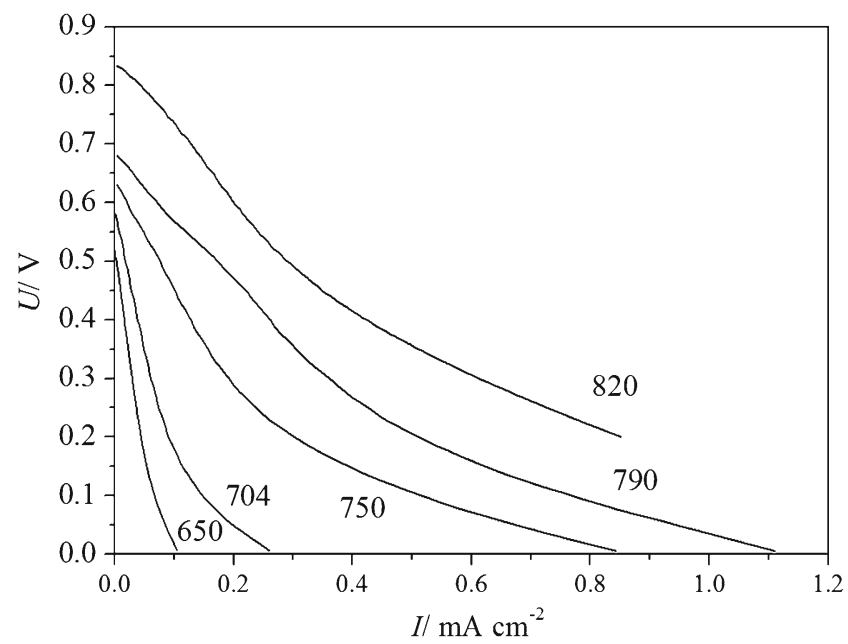

Fig. $9 U-I$ curves recorded for cell (4) fed with needle particle sizes of graphite

An additional effect on the electrochemical oxidation of carbon particles is exerted by the morphology of graphite powders. This can be seen in Fig. 9, which presents the family of $U-I$ curves recorded for the DC-SOFC (type 4) supplied with a needle graphite. For this fuel, very low current densities are observed in comparison to these obtained from the DCSOFC supplied with isometric carbon particles (Fig. 8a-b and Table 2). In contrast to crystallographic disorder and particle shapes, electrical conductance has a lesser effect on the performance of the DC-SOFC (4).

Taking into account the conclusion regarding the correlation between the crystallographic disorder of fuel and performance of the DC-SOFC, one might expect that the highest current and power densities would be obtained from the DCSOFC fed with carbon black fuels. The families of $U-I$ and $P-I$ curves determined for the DC-SOFC supplied with carbon black powders (samples E and F) are presented in Fig. 10. Indeed, in this case, considerably higher current and power densities are observed in comparison to the DC-SOFC fed with graphite powders.

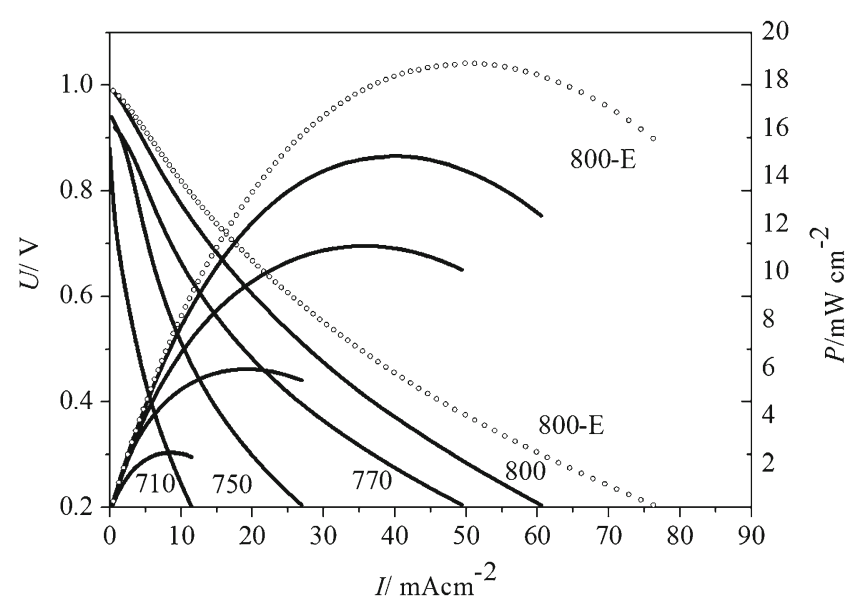

Fig. $10 U-I$ curves recorded for cell (4) fed with carbon black F or E 

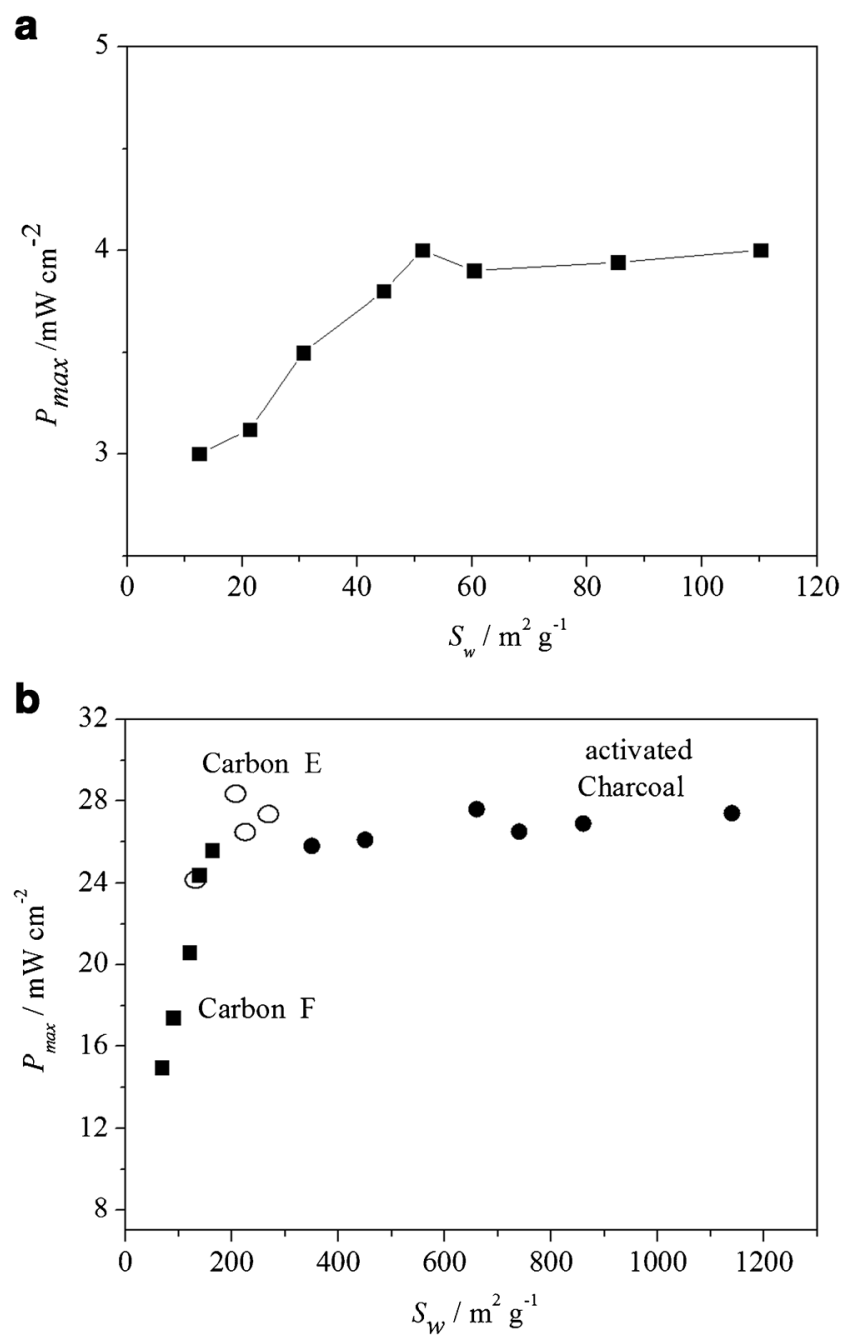

Fig. 11 a Effect of surface area $\left(S_{w}\right)$ of applied graphite powders from series A on the power $\left(P_{\max }\right)$ acquired from cell (4). Data for $800{ }^{\circ} \mathrm{C}$. Ar atmosphere over fuel. b Impact of surface area $\left(S_{w}\right)$ of applied carbon black or charcoal on the power $\left(P_{\max }\right)$ acquired from cell (4). Data for $800{ }^{\circ} \mathrm{C}$. Ar atmosphere over fuel

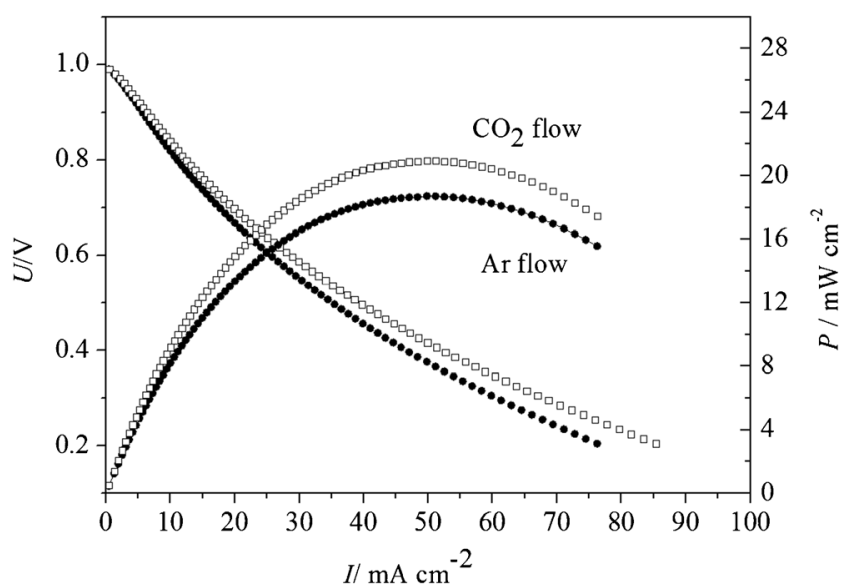

Fig. $12 U$-I curves recorded for cell (4) fed with carbon black E under $\mathrm{Ar}$ and $\mathrm{CO}_{2}$ flow. Curves recorded at $800{ }^{\circ} \mathrm{C}$
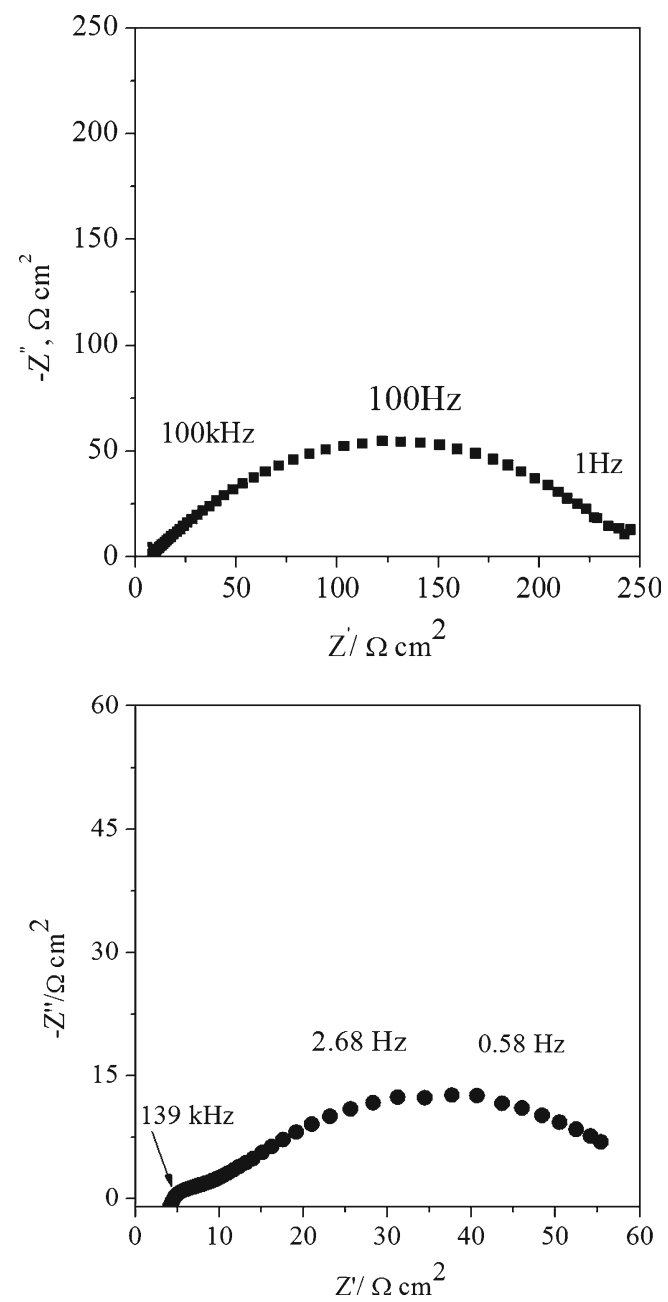

Fig. 13 Impedance spectra recorded at $700{ }^{\circ} \mathrm{C}$ for DC-SOFC (4) fed with a graphite powder $\mathrm{D}$ or $\mathbf{b}$ carbon black $\mathrm{F}$

The impact of the surface area of graphite powder or carbon black powder used as a solid fuel on the acquired electrical power from cell (a) at $800{ }^{\circ} \mathrm{C}$ is presented in Fig. 11a-b.

As the particle size of graphite powder decreases, performance improves slightly due to an increase in the surface area between the carbon solid particles and the oxide electrolyte. Consequently, reactions with carbon particles are intensified, and the activation of losses is reduced. At higher temperatures, the oxidation of carbon might possibly proceed through $\mathrm{CO}$ in a gaseous phase. To determine the impact of $\mathrm{CO}$ on a potential additional improvement in the performance of cell (4), the effect of a $\mathrm{CO}_{2}$ atmosphere on the system was analyzed. In Fig. 12 , the $U-I$ and $P-I$ curves obtained at $800{ }^{\circ} \mathrm{C}$ under $\mathrm{Ar}$ and $\mathrm{CO}_{2}$ atmospheres were compared. As can be seen, there is

Table 3 Polarization resistance $\left(R_{p k}\right)$ of the cathode measured using a symmetrical cell

\begin{tabular}{lllll}
\hline Temperature ${ }^{\circ} \mathrm{C}$ & 550 & 600 & 700 & 800 \\
\hline$R_{p k} / \Omega \mathrm{cm}^{2}$ & 64.3 & 18.6 & 4.3 & 1.1 \\
\hline
\end{tabular}


a

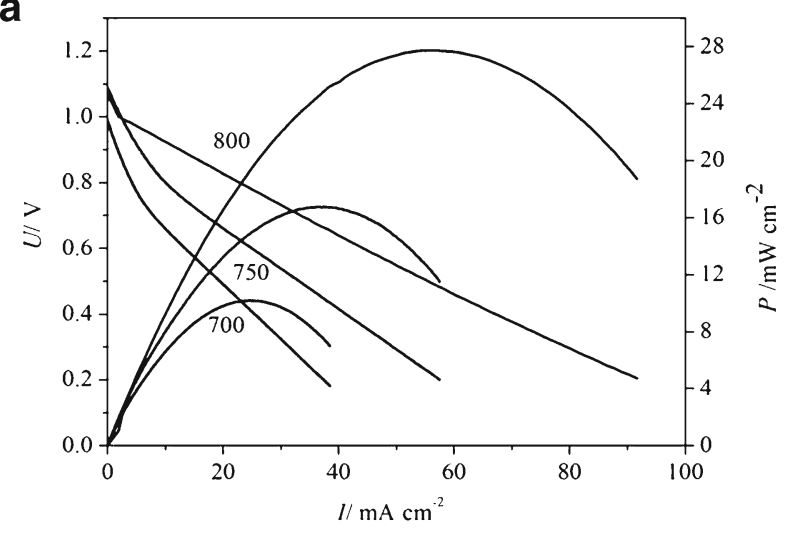

C

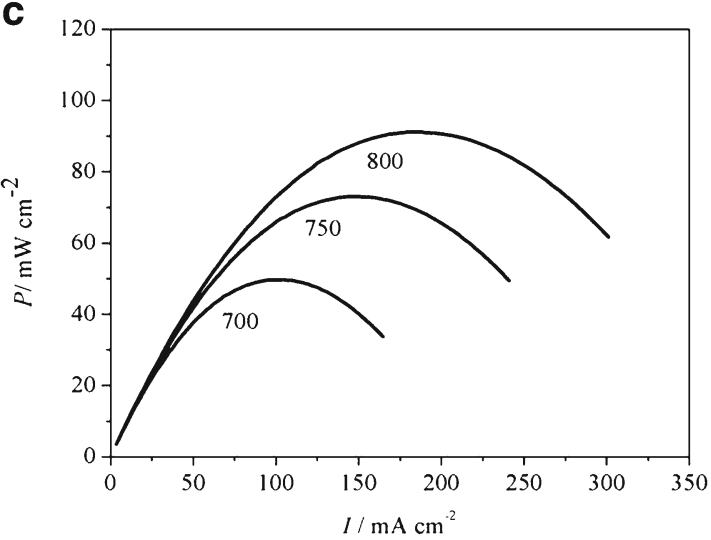

b

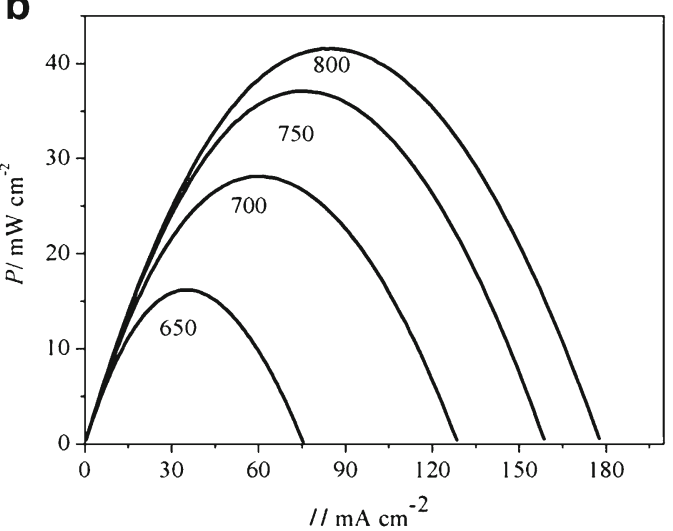

Fig. $14 P-I$ curves recorded for DC-SOFC (5) fed with a graphite A, b graphite D, or c carbon black E

practically no difference between power measurements performed under these conditions.

Figure 13a-b shows the impedance spectra recorded for DC-SOFCs (4) fueled with graphite powder (sample D) and carbon black (sample F) at $\mathrm{OCV}$ at $700{ }^{\circ} \mathrm{C}$. The impedance of the cathode used in this study was characterized separately using a symmetrical cell; its impedance parameters are collected in Table 2. As can be seen, the dominant effect on the impedance of the DC-SOFC fueled with either graphite or carbon black is produced by anodic processes. These data show that anodic polarization resistance restricts the performance of DC-SOFC (4) (Table 3).

The electrochemical oxidation of graphite and carbon black powders on the cermet anode material Ni-YSZ was also investigated. As opposed to cell (4), in this case, an additional impact on the performance of DC-SOFC (5) is made by gaseous $\mathrm{CO}$, which is the product of a Boudouard reaction (2). Figure $14 \mathrm{a}-\mathrm{c}$ presents the typical $P-I$ curves recorded for cell (5) supplied with graphite and carbon black powders. As can be seen, the performance of cell (5) fed with graphite, in contrast to carbon black, seems to be limited. These results indicate that disordered carbonbased fuels appear to be prospective solid fuels for DCSOFC applications.

\section{Conclusions}

1. Various graphite and carbon black powders were tested as potential fuels for a direct carbon fuel cell with a solid oxide electrolyte.

2. The samples of investigated graphite and carbon black powders were examined by ultimate analysis, XRD, Raman spectroscopy, and thermal analysis (DTA/DSC-TG), showing that the investigated samples were pure-phase carbon-based materials. In graphite-based samples, different degrees of structural disorder were noted. No considerable thermal effect or mass losses were detected by means of the thermal analysis method.

3. In electrical conductivity measurements carried out for the investigated carbon-based materials, the carbon black materials showed slightly higher conductivities than the graphite-based materials.

4. The electrochemical oxidation of graphite as well as of carbon black-based solid fuels on the oxide surface of an $8 \mathrm{YSZ}$ electrolyte and the active surface area of Ni-YSZ anode materials was investigated. It was found that the degree of disorder of the crystallographic structure of solid fuels had the greatest impact on the electrochemical oxidation process. The carbon black-based solid fuels 
with disordered carbon structures seem to be better solid fuels than graphite powders for DC-SOFCs.

5. The performance of a DC-SOFC depends on the surface area and particle shape of the applied carbon powder. The isometric regular shape of carbon particles and the larger surface area lead to a better electrical contact between the solid fuel and the surface of oxide electrolytes, which leads in turn to a decrease in ohmic polarization.

6. In the case of a Ni-YSZ cermet anode, disordered carbon is a better solid fuel in comparison to graphite powders.

Open AccessThis article is distributed under the terms of the Creative Commons Attribution License which permits any use, distribution, and reproduction in any medium, provided the original author(s) and the source are credited.

\section{References}

1. Sano F, Akimoto K, Wada K, Nagashima M (2013) Energy Procedia 37:7582-7589

2. Giuffrida A, Bonalumi D, Lozza G (2013) Appl Energy 110:44-54

3. Zecevic S, Patton E, Parhami P (2004) Carbon 10:1983-1993

4. Giddey S, Badwal S, Kulkarni A, Munnings C (2012) Prog Energy Combust Sci 38:360-399

5. Kacprzak A, Kobyłecki R, Bis Z (2013) J Power Sources 239:409_ 414
6. Cassir M, McPhail SJ, Moreno A (2012) Int J Hydrogen Energy 37: $19345-19350$

7. Dicks AL (2006) J Power Sources 156:128-141

8. Horita T, Sakai N, Kawada T, Yokokawa H, Dokiya M (1995) J Electrochem Soc 142:2621-2624

9. Liu R, Zhao CH, Zeng F, Wang S, Wen T, Wen Z (2010) J Power Sources 195:480-482

10. Yu X, Shi Y, Wang H, Cai N, Li C, Tomov RI, Hanna J, Glowacki B, Ghoniem A (2013) J Power Sources 243:159-171

11. Xie Y, Tang Y, Liu J (2013) J Solid State Electrochem 17:121-127

12. Zhou J, Ye XE, Shao L, Zhang XP, Qian JQ, Wang SR (2012) Electrochim Acta 74:267-270

13. Chien AC, Corre G, Antunes R, Irvine JT (2013) Int J Hydrogen Energy 38:8497-8502

14. Wu Y, Ch S, Zhang C, Ran R, Zhao Z (2009) Electrochem Commun 11:1265-1268

15. Dudek M, Tomczyk P (2011) Catal Today 176:388-392

16. Dudek M, Tomczyk P, Juda KL, Tomov R, Glowacki BA, Batty S, Risby P, Socha R (2012) Int J Electrochem Sci 7: 6704-6721

17. Zickler GA, Smarsly B, Gierlinger N, Peterlik H, Paris Q (2006) Carbon 44:3239-3246

18. Ungár T, Gubicza J, Ribárik G, Pantea C, Zerda T (2002) Carbon 40: 929-937

19. Kurmaev EZ, Shamin SN, Kolobova KM, Shulepov SV (1986) Carbon 24:249-253

20. Tuinstra F, Koenig J (1970) J Chem Phys 53:1126-1130

21. Cherepy NJ, Krueger R, Fiet KJ, Jankowski AF, Cooper JF (2005) J Electrochem Soc 152:A80-A87

22. Cooper J (2007) Direct conversion of coal derived carbon in fuel cells. In: Basu S (ed) Recent trends in fuel cell science and technology. Anamaya Publishers, New Delhi, India 